\title{
Whatever happened to William Osler's library?
}

\author{
Christopher Lyons and David S. Crawford
}

\begin{abstract}
Sir William Osler bequeathed his library to McGill University in 1919, and the 8000 volumes arrived in Montreal a decade later. Then, as now, the collection consisted of both primary works (rare books) and secondary commentaries, and current works on the history of the health sciences. In the last 80 years, the collection has grown considerably, and the library now adds about 1000 books each year, mainly current publications, and receives 200 current serial titles. The Osler Library, which is one of the largest "history of medicine" libraries in the world and the largest in Canada, tries to collect current material on the history of the health sciences from all over the world and attempts to collect all medical history published in Canada. The Osler offers its resources to researchers through its Web site, publications, and Research Travel Grant program.
\end{abstract}

The librarian of today, and it will be true still more of the librarians of tomorrow, are not fiery dragons interposed between the people and the books. They are useful public servants, who manage libraries in the interest of the public... Many think still that a great reader, or a writer of books, will make an excellent librarian. This is pure fallacy [1].

\section{William Osler}

William Osler was born in Bond Head, Canada West (now Ontario) in 1849. After commencing his education in Toronto, he became a student at McGill University in Montreal and graduated in medicine in 1872. Osler's life and career have been well described in two major biographies $[2,3]$, but, briefly, his career took him from being a professor at McGill (1874-1884) to the University of Pennsylvania (1884-1889), to Johns Hopkins University (1889-1905), and finally to Oxford as Regius Professor of Medicine (19051919) (Fig. 1).

When Osler died in 1919, he was probably the most famous doctor in the western world. Along with his many articles, letters, and lecture presentations, he authored and edited the best-selling textbook, Principles and Practice of Medicine. The textbook went through eight editions from 1892 to his death, was translated into French, German, Spanish, Portuguese, Chinese, and Russian, and continued to be published in further editions after he died [4]. "Oslerian medicine" was of great interest, and "Osler Clubs" were established in many places. Some of the clubs, such as those in the United States, London, Japan, and at McGill, continue today; though now they more often discuss "history" and "Osler" rather than current medical practice. Osler was an early proponent of the need to listen to the patient and realized that disease and health are closely connected to living conditions. He was strongly influenced by Sir Thomas Browne, whose 17th century work Religio Medici guided Osler throughout his career. Osler was awarded a baronetcy in 1911 and held numerous honorary degrees. He was also very human and enjoyed teasing and practical jokes. In his letters, speeches, and articles, he clearly comes across as a person whom it would have been a pleasure to meet. Osler created a mischievous alter ego, Egerton Yorrick Davis, under whose name a variety of letters and articles appeared on subjects ranging from the fanciful customs of the "Indian Tribes About Great Slave Lake" to vaginismus and Peyronie's disease. Such was the notoriety of "EYD" that some medical writers continue to use this pseudonym today [5].

Osler was also a bibliophile and a strong supporter of libraries and library associations. While at McGill he served on the Faculty Library Committee, in Philadelphia he served on the Library Committee of the College of Physicians, in Baltimore he was a member of the Library Committee of the Medical and Chirurgical Faculty of the State of Maryland, and at Oxford he was a Curator of the Bodleian Library. Osler was one of the founders and second president of the Association of Medical Librarians (which became the Medical Library Association) [6] and later was one of the founders and first and only president of the short-lived Association of Medical Libraries of Great Britain and Ireland [7,8]. He donated books to libraries throughout his career — sometimes with such enthusiasm that he tried to donate the same book several times. For example, he attempted to donate a second original Vesalius to the New York Academy of Medicine! Osler was also a book collector; in his lifetime, he assembled a personal collection of about 8000 items. His aim was to create a library containing a record of the history of medicine, and he attempted to include both primary works and secondary commentaries. His collection included about 140 incunabula (books published before 1501), many rare primary works such as first editions of Vesalius' de Fabrica and Harvey's de Mortu Cordis, and many commentaries and

C. Lyons. ${ }^{1}$ Assistant History of Medicine Librarian, Osler Library of the History of Medicine, McIntyre Medical Sciences Building, McGill University, 3655 Promenade Sir-William-Osler, Montreal, QC H3G 1Y6, Canada.

D.S. Crawford. Emeritus Librarian, McGill University. Present address: 135 George Street South, Toronto, ON M5A 4E8, Canada.

${ }^{1}$ Corresponding author (e-mail: christopher.lyons@mcgill.ca).

JCHLA / JABSC 27: 9-13 (2006) 
Fig. 1. Sir William Osler, 1849-1919.

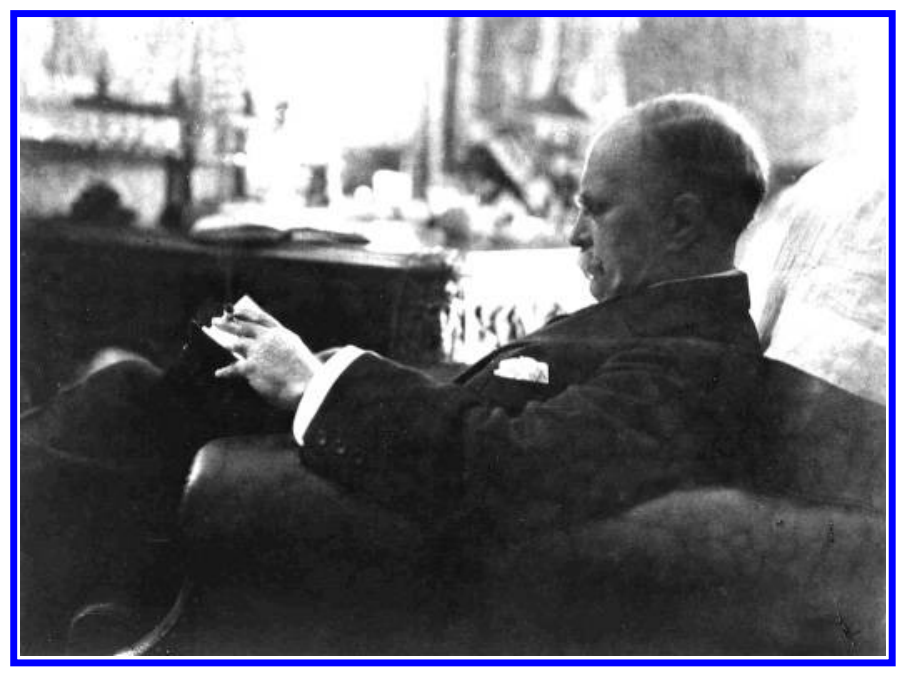

secondary works on the history of medicine. His collection also contained books showing the relationship between medicine as art and medicine as science and contained a sizable section of books on medicine in literature.

In about 1912, Osler decided to leave his library to McGill University. When he died in 1919, the whole collection, with the exception of a few items donated to other libraries, was bequeathed to McGill's Faculty of Medicine. He made this generous gift for several reasons. In his introduction to the catalogue, the Bibliotheca Osleriana [9], he wrote "as a young, untried man, McGill College offered me an opportunity to think and to work; but what is more, the members of the Medical Faculty adopted me, bore with vagaries and aggressiveness, and often gave practical expressions of sympathy with schemes which were costly and of doubtful utility." He was also moved by pride in his alma mater and by "loyalty to the country of one's birth and breeding." Because of the need to prepare a suitable home at McGill and, more importantly, because of the need to complete the catalogue, it took 10 years for the collection to reach Montreal. Osler had started to compile the catalogue before his death. It was completed in Oxford (under the watchful eye of Lady Osler) by four of his friends, led (very slowly!) by his cousin's son William Willoughby Francis. This catalogue has been described as "probably the most complete well-annotated bibliography in the history of medicine. It reveals Osler's character better than any of his writings and stands as a monument to him" [10]. The Bibliotheca was originally published in 1929 and was reprinted, with corrections and an additional prologue, in 1969. It remains in print and is available from the library. The introductory material (including Osler's Introduction) has been reproduced on the Osler Library's Web site (http://www.mcgill.ca/osler-library/).

A recent article [11] gives much historical background on the "physical library" (and describes the recent renovation), but, in brief, the room prepared for the collection at McGill was designed by the famous Montreal architect Percy Nobbs. It was inserted into the Strathcona Medical Building, adjacent to the Medical Library. The central focus of the library (then comprising only one large room, now called the Osler Room) was a bronze plaque of Osler, under which the ashes of both Sir William and Lady Osler (who died in 1928) were
Fig. 2. Mezzanine of the Osler Library of the History of Medicine, McGill University.

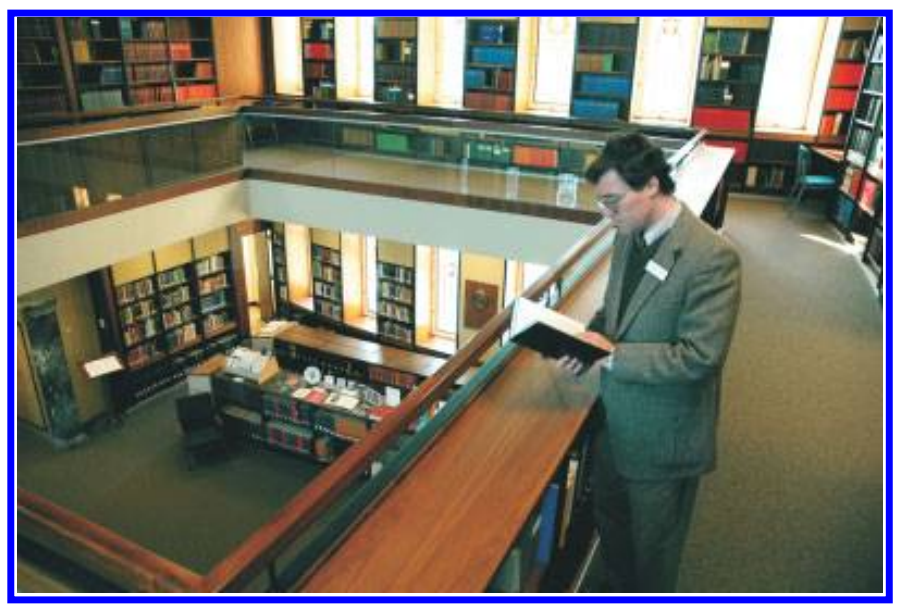

placed. The library opened, amid a great deal of pomp and ceremony, in 1929. In his biography of Osler, Canadian historian Michael Bliss has described the Osler Room as "a shrine, architecturally a cross between a church and a mausoleum."

William Willoughby Francis, who had a medical degree from Johns Hopkins, had been appointed Osler Librarian by McGill University in 1921 and, tellingly, often referred to himself as "Osler's Librarian". Until his death in 1959, he maintained, in the rather biting words of one commentator, "the Mecca for Osler devotees, a memorial and museum designed to perpetuate the inspiration which Osler had instilled in his followers... he kept Osler in the forefront and never allowed the Library to become anything more than Osler's Library" [12]. Osler had instructed that the library should have a Board of Curators, whose existence and composition was clearly influenced by the Curators of the Bodleian Library [13]. Though the library did grow during the years of Francis" "reign", the meetings of the Curators were not easy because Francis strongly resisted any attempt to expand "Osler's Library" [14]. However, by 1963, despite this resistance, the library had doubled in size, to about 17500 volumes.

Much has changed since Francis died. First, in 19641965, the library was moved into the new McIntyre Medical Sciences Building. This was not a simple move as it involved not only the library collections but also the original Nobbs-designed Osler Room. This beautiful room was dismantled and rebuilt inside a panhandle-shaped wing adjacent to the Medical Library. This wing provided some expansion space for both the collection and the staff and allowed the creation of the Wellcome Camera (Fig. 2). Shortly afterwards, all of the pre-1851 material in the adjacent Medical Library was transferred to Osler. The McGill Medical Library (later named the Health Sciences Library and now the Life Sciences Library), which was founded in August 1823, is Canada's oldest medical library, and the approximately 4000 volumes transferred added further treasures (and the sale of the inevitable duplicates brought in some additional funds). Francis had taught the "history of medicine" at McGill, and by the mid-1960s, a more formal Department of the History of Medicine was established. This department 
Fig. 3. Front entrance of the Osler Library of the History of Medicine, McGill University.

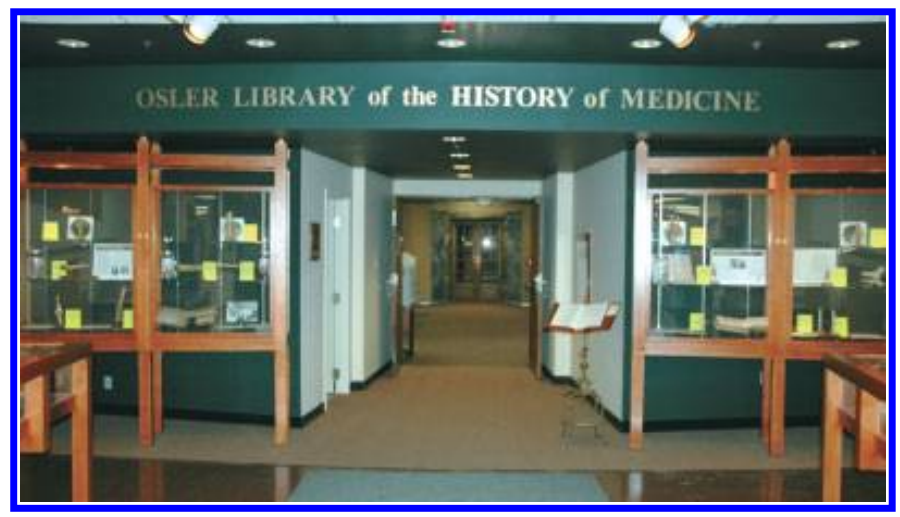

was also allocated space adjacent to the two libraries. In the mid-1970s, the Osler Library and the department were allocated some adjacent space, and in April 1978, the Francis Wing opened. This provided a larger rare book area, more offices for both the library and the department, and provided some additional space for the circulating collection. However, by the late 1990s, this space had been (more than) filled and the department had expanded (and changed its name to the Department of Social Studies of Medicine to better reflect its interests in the history, anthropology, and sociology of medicine). As the close physical and intellectual links between the Osler Library and the Health Sciences Library were mutually beneficial, and since it was virtually impossible to move the Nobbs-designed Osler Room once again, the decision was made to relocate the department. Most of the space was then allocated to the Osler Library, and the whole area was renovated to provide additional shelving, better security and environmental conditions, and enhanced study areas and offices. The John P. McGovern Foundation largely underwrote the cost of this major project, and the newly expanded library reopened in November 2002 (Fig. 3).

Osler's original donation had been composed of both rare books and current secondary works, and, in fact, the Bibliotheca includes several items published after his death. The library now adds about 1000 recently published books each year (most of which are available for loan) and also acquires outof-print or rare books by both donation and purchase. The library has two major collections of medical theses: about 1100 from the University of Edinburgh (1790-1821) and about 30000 French theses from the Université de Paris (1796-1920) [15,16]. The Osler Library collection now totals about 60000 printed volumes, excluding the theses, and the library subscribes to approximately 200 current serials in all aspects of the history of the health sciences. As the Osler Library is a component of the McGill University Library, it benefits from McGill University's licensing of e-book and journal collections such as Early English Books Online and Early Canadiana Online and, of course, can draw on printed material in related subject areas held in other McGill libraries. The Osler is unusual for a history of medicine collection as it contains both rare and circulating material, and it is now one of the largest history of medicine libraries in the world - certainly the largest in Canada. In addition to books and archives, the library has a small and static collection of medical artifacts, including one of Osler's microscopes and one of Norman Bethune's pneumothorax machines.

Information on all of the library's printed and manuscript collections is included in the McGill Library catalogue (http:// muse.mcgill.ca/F). As a service to students and researchers, the library has tried to make some of its reference resources available through the library's Web site. These include databases of the library's reprint and medical almanac collections; the Canadian Health Obituary Index, which lists 19th and 20th century obituaries of health professionals; and the Bibliography of Canadian Health Sciences Periodicals (compiled by David S. Crawford and based on the earlier printed bibliography by Roland and Potter). The library has quite substantial archival collections, and collection-level records for most of these 150 fonds are also available on the library's Web site; records for the rest will be added in the next few months. We hope to add links to these from the online catalogue in due course. Most of these fonds are connected to Osler, the Osler family, McGill, and Montreal medicine, but there are also the documents used by Beatrice Simon (who was a McGill librarian) when she compiled her survey of Canadian medical school libraries [17] and the working papers of M.A. (Babs) Flower as she wrote Libraries Without Walls [18]. The Osler is the official archive for both the Committee on Libraries of the Association of Faculties of Medicine of Canada (AFMC) and the Canadian Health Libraries Association (CHLA) and has the working documents of the ad hoc committee whose work led to the establishment of the CHLA.

The Osler Library tries to collect printed material on the history of the health sciences from all over the world in all languages but makes special efforts to buy any material published on the history of Canadian health sciences, including institutional histories and biographies and autobiographies of health care practitioners. (In the case of Canadian material, the library tries to add even "non-academic" primary and secondary material.) Because much of this Canadian material is somewhat ephemeral, is not published by regular publishers, and is frequently only available locally, it is often a challenging task to discover and then buy this material. Because the McGill Life Sciences Library has had a longstanding policy of not withdrawing older editions of books and will add significant "middle-aged" material that is donated, the Osler and its users can rely on a vast continuum of resources. The Life Sciences Library holds primary material published from 1851 onward (but only adds material published from 1915 onward), while the Osler adds historical works published in all time periods and primary works published up to 1914. At some point it is anticipated that a further tranche of older primary material (presumably 18511914) will be transferred to the Osler Library, but the space to house and the staff to properly manage this material are not presently available. As the holdings of both libraries are listed in the McGill Library Catalogue, this separation of resources is not a major problem for our users. Although the environmental and security conditions in the Life Sciences Library's storage facility are not ideal, they are currently under review.

The Osler Library has a staff of four: two librarians and two library assistants. The Osler relies on the Life Sciences Library for circulation services and the McGill Library 
Technical Services for acquisitions and cataloguing. The Osler staff, in addition to having responsibility for collection development, conservation, and reference, participate in McGill courses involving the library's resources. The library has also recently developed a number of student guides to the literature, which are available on the library's Web site. The Osler has an active Friends group and publishes the Osler Library Newsletter and a series of books on medical history, Osler Library Studies in the History of Medicine. Information on these and full-text of recent newsletters are available on the library Web site. To assist scholars who need to use the library's resources, we sponsor an annual Research Travel Grant to allow scholars to travel to Montreal. Sir William's original instruction was the following: "The library is for the use of students of the history of science and of medicine, without any other qualifications, and I particularly wish that it may be used by my French Canadian colleagues, who will find it rich in the best of French literature." This aim has been fulfilled, and by using the Internet, the library's resources are being made available to students and researchers throughout the world. Although the library is no longer only "Osler's Library" and has become "The Osler Library", it continues to fulfill the aim set out by William Osler almost a century ago — to provide Canadians, in particular, with a world-class collection describing the development of the health sciences.

A library represents the mind of its collector, his fancies and foibles, his strength and weakness, his prejudices and preferences. Particularly is this the case if to the character of a collector he adds - or tries to add - the qualities of a student who wishes to know the books and the lives of the men who wrote them. The friendships of his life, the phases of his growth, the vagaries of his mind, all are represented [19].

William Osler

\section{References}

1. Osler W. The library school in the college. Libr Assoc Rec. 1917; 17:288.

2. Cushing H. The Life of Sir William Osler. Oxford: Clarendon Press; 1925.

3. Bliss M. William Osler: a life in medicine. Toronto: University of Toronto Press; 1999.

4. Golden RL. A history of William Osler's The principles and practice of medicine. Osler Library studies in the history of medicine, No. 8. Montreal: Osler Library; 2004.

5. Golden RL. The works of Egerton Yorrick Davis, MD: Sir William Osler's alter ego. Osler Library studies in the history of medicine, No. 3. Montreal: Osler Library; 1999.

6. Connor JJ. Guardians of medical knowledge: the genesis of the Medical Library Association. Lanham, Md.: Medical Library Association/Scarecrow Press; 2000.

7. Crawford DS. The Medical Library Association of Great Britain and Ireland. Health Info Libr J. 2004;21:266-68.

8. Ferguson V. The professionalization of health librarianship in the UK between 1909 and 1978. Health Info Libr J. 2005;22(Suppl 1): 8-19.

9. Bibliotheca Osleriana: a catalogue of books illustrating the history of medicine and science. Oxford: Clarendon Press; 1929. Reprinted with addenda and some additional material; Montreal: McGill - Queens University Press; 1969.
10. Morton LT. A medical bibliography (Garrison and Morton): an annotated checklist of texts illustrating the history of medicine. Philadelphia: Lippincott; 1970.

11. Miller PJ. Preserving medical history: recent renovations to the Osler Library. In: Conner E, editor. Planning, renovating, expanding, and constructing library facilities in hospitals, academic medical centers, and health organizations. Binghamton, N.Y.: Haworth; 2005. p. 25-42.

12. Summary of impressions arising from a close examination of the curators' minute book. Minutes of the Board of Curators, Osler Library of the History of Medicine, 1967

13. Grant N. Sir William and the Osler Library's Board of Curators. Osler Libr Newsl. 1969;2:1-5.

14. Wallis F. I am Osler's nephew and librarian: W.W. Francis at the helm of the Osler Library. Osler Libr Newsl. 1995;80:1-5.

15. Crawford DS. Edinburgh University medical theses at the Osler Library. Osler Libr Newsl. 2004;101:1-6.

16. Lyons C. From Osler's library to the Osler Library of the History of Medicine: an overview of the Osler Library of the History of Medicine, McGill University, Montreal. Can Bull Med Hist. 2006. In press.

17. Simon BV. Library support of medical education and research in Canada: report of a survey of the medical college libraries of Canada, together with suggestions for improving and extending medical library service at local, regional, and national levels. Ottawa: Association of Canadian Medical Colleges; 1964.

18. Flower MA. Libraries without walls: blueprint for the future: report of a survey of health science library collections and services in Canada. Toronto: Canadian Health Libraries Association; 1987. Available at http://www.chla-absc.ca/documents/ wallsfinal.pdf [cited 2006 Jan 1].

19. Osler W. The collecting of a library. In Bibliotheca Osleriana: a catalogue of books illustrating the history of medicine and science. Oxford: Clarendon Press; 1929. Reprinted with addenda and some additional material; Montreal: McGill Queens University Press; 1969.

\section{Appendix A}

\section{A note to Canadian health librarians}

As explained in this article, the Osler Library is both a rare book library and a circulating library on all aspects of the history of the health sciences. Information on our holdings is fully available through the McGill library catalogue (http://muse.mcgill.ca/F). Our holdings are reported to AMICUS, and we participate fully in the interlibrary loan system (though rare and fragile books do not circulate and must be used on site). As we are primarily staffed to serve the needs of McGill University staff and students, we cannot accept general reference questions on the history of medicine but are happy to try to answer questions related to William Osler himself or to unique material that we hold.

If you would like a copy of the Osler Library Newsletter sent to your library, please contact us at osler.library@mcgill.ca. If you prefer, it is freely available at http://www.mcgill.ca/ osler-library/.

The library maintains an active and annotated Web listing of history of medicine Web resources. If you wish to suggest additions or corrections, we would be pleased to hear from you (christopher.lyons@mcgill.ca).

The Osler is very keen to obtain material (by donation or purchase) on all aspects of the history of the health sciences in Canada and actively collects current and retrospective 
material published in Canada on all aspects of health. If your institution has published a history or you know of any locally published items of medical history or biography (and they are not listed in our catalogue), please let us know (osler.library@mcgill.ca).
If you or your patrons are interested in applying for the annual Research Travel Grant, please see the library Web site. Applications for 2006 are no longer being accepted; however, the deadline for 2007 applications is 31 December 2006. 